\title{
Wind Energy
}

\author{
From Coast to Coast, Wind Turbines Are Generating Electricity
}

Wind is caused by the earth's rotation and by air-pressure differences from uneven heating of the earth's surface. The energy of the wind is widely distributed geographically and relatively concentrated, and it has a long history of use as an energy source. In general, wind-energy resources are best along coastlines, at elevated sites in hilly terrain, and in the Great Plains, although usable wind resources are available in every state.

The U.S. Department of Energy (DOE) has compiled an atlas containing wind-resource maps for the entire world. These reports-available through the National Renewable Energy Laboratory-provide wind data that help to predict the performance of wind turbines at virtually any location.

Wind turbines are machines that capture wind energy with a rotor formed by two or three propellerlike blades attached to a central hub mounted on a shaft. This rotor assembly converts wind velocity to rotary motion. And the rotating shaft turns a generator to convert mechanical energy to electrical energy. Wind is faster and less turbulent at 100 feet or more above the ground. So wind turbines are mounted on tall towers to capture the most energy.

Modern wind turbines, such as this $50-\mathrm{kW}$ system, can be used in both stand-alone and hybrid applications.

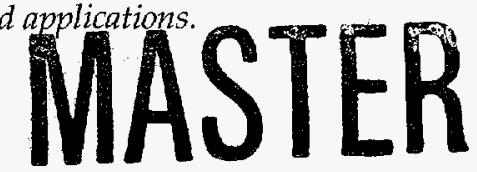

\section{What are the opportunities?}

Wind applications may be either stand-alone or grid-connected. Standalone applications involve windgenerated power apart from utility lines and established power grids. The best opportunities for small wind turbines, which generate less than 50 kilowatts, are stand-alone applications in which grid power is more than 1 kilometer ( 0.6 mile) away. The turbines are designed for high reliability, minimum maintenance, and lower wind resources. Complete wind-power systems using batteries and modern power electronics can readily replace small diesel- and propane-powered generators. They can also be helpful in mitigating the cost of environmental compliance.

Typical small wind turbine applications include

- Telecommunications

- Remote residences

- Cathodic protection

- Navigation aids

- Monitoring/security

- Pumping/irrigation

- Desalination/treatment

- Crisis response

- Environmental compliance

- Peak shaving

- Uninterruptible power.

Grid-connected applications involve wind-generated power-usually from an interconnected group of turbines in a wind farm - that feeds into a central power distribution grid. Large wind turbines, which generate more than 100 kilowatts, are designed to achieve minimum costs of energy when installed in high-wind resource areas. These units are typically clustered in wind farms of 1 megawatt or more, where they provide bulk power 


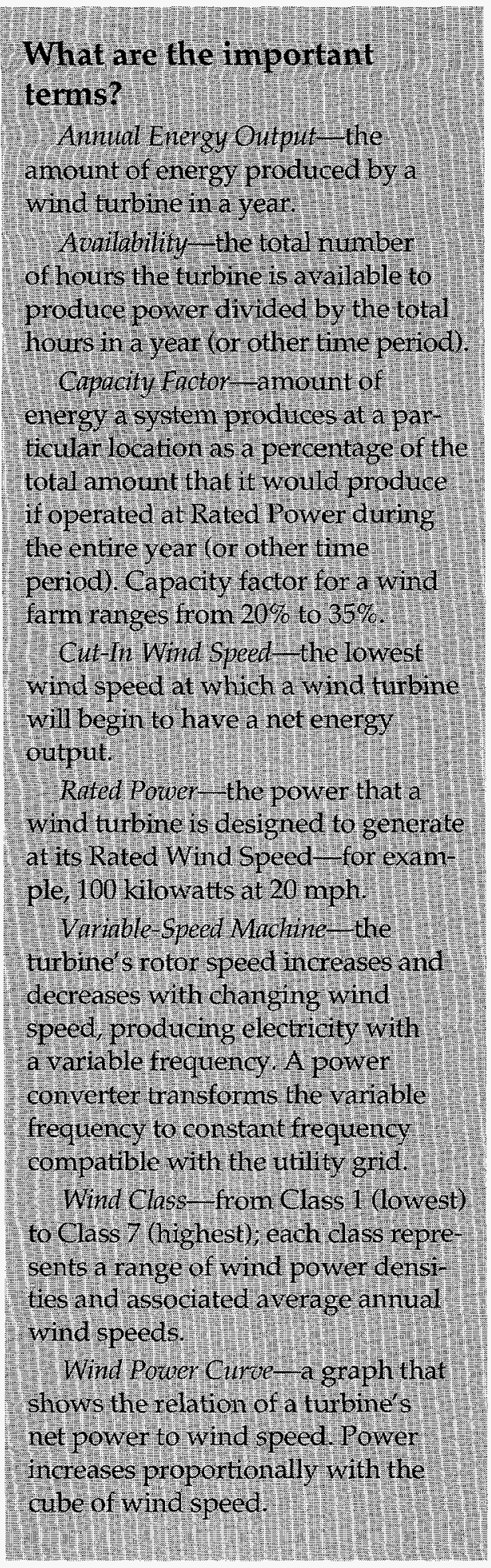

generation at costs competitive with new fossil fuel plants.

Extensive sections of federal land may be leased to a developer who will site a wind farm on this land and pay the government for the use of the land. Under a power-purchase agreement, a supplier bears the cost and risks associated with installing the wind equipment in return for guaranteed purchase of power during a specified period. The wind farm may meet a federal agency's power needs in the vicinity, or the power can be sold to someone else. Also, wind turbines operate in harmony with other land uses such as farming and ranching.

A hybrid system using photovoltaics and wind turbines may meet overall power needs better than either system could alone. This is true if the solar and wind resources are complementary-for example, if in the winter, as sunlight decreases, the wind resource increases.

\section{What is required?}

An environmental impact statement is required for any construction or refurbishment involving power generation systems

For stand-alone applications, the following criteria are preferable:

- Diesel or fossil fuel must be transported to site for power generation

- Cost of electricity is high (greater than 12 cents per kilowatt-hour)

- Wind resource is moderate (at least class 3 )

- Air-pollution requirements pose a problem for diesel system.

For grid-connected applications, the following criteria are preferable:

- Diesel or fossil fuel must be transported to site for power generation

- Cost of electricity is high (greater than 8 cents per kilowatt-hour)

- Must meet air pollution requirements

- Near transmission lines with adequate capacity

- Wind resource has been measured and is moderate to high (class 3 to 7 ).

\section{What does it cost?}

Wind-energy costs have improved dramatically during the past decade. For grid-connected applications of large wind turbines, energy costs typically range from 4-10 cents per kilowatt-hour. For grid-connected. applications of small wind turbines, energy costs typically range from $7-15$ cents per kilowatt-hour. And for stand-alone applications of small wind turbines, energy costs typically range from 8-30 cents per kilowatt-hour. Costs for all applications are continuing to decline as technology advances.

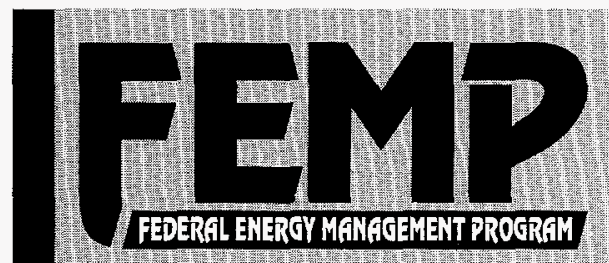

\section{For More Information}

For additional information about vind energy, contact:

Ed Camion

National Renewable Energy

Laboratory

1617 Cole Boulevard

Golden, CO 80401-3393

(303) $384-6920$

$\operatorname{Eax}:(303) 384-6901$

For a list of manufacturers, contact:

American Wind Energy Association 122 C Street, NW, 4 th Floor

Washington, DC 20001

(202) 3832500

Fax. (202) 383-2505

To inquire about renewables design assistance a vallable through FEMP contact:

Nancy Carilisle

National Renewable Energy

Laboratory

1617 Cole Boulevard

Golden, CO 80401-3393

(303) 3847509

IEMP I Lelp Line 1-800-566-2877

Fax: $1-2025866-3000$

Internet: http./ wwweren.doe gov / femp

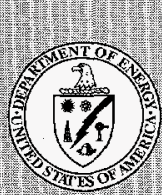

Prodiced for the US. Department of Energy (DOE) by the National Renewable Energy I Lboratory. a DOE national laboratory DF96007882 $\quad 12 \frac{2}{6}-289695$ DOE/CO-10096267

A revision of NREL/TP-472-7028 May 1996 


\section{DISCLAIMER}

Portions of this document may be illegible in electronic image products. Images are produced from the best available original document. 



\section{DISCLAIMER}

This report was prepared as an account of work sponsored by an agency of the United States Government. Neither the United States Government nor any agency thereof, nor any of their employees, makes any warranty, express or implied, or assumes any legal liability or responsibility for the accuracy, completeness, or usefulness of any information, apparatus, product, or process disclosed, or represents that its use would not infringe privately owned rights. Reference herein to any specific commercial product, process, or service by trade name, trademark, manufacturer, or otherwise does not necessarily constitute or imply its endorsement, recommendation, or favoring by the United States Government or any agency thereof. The views and opinions of authors expressed herein do not necessarily state or reflect those of the United States Government or any agency thereof. 
